\title{
"Violence" in Sport and the Violenti non fit Iniuria \\ Defence: A Perspective on the Death of the Cricket Player Phil Hughes
}

\section{P Labuschagne ${ }^{\star}$}

\section{P.E.R}

Pioneer in peer-reviewed, open access online law publications

Author

Pieter Labuschagne

Affiliation

University of South Africa

Email

labuspa@gmail.com

Date of submission

10 May 2017

Date published

16 March 2018

Editor Prof O Fuo

How to cite this article

Labuschagne P "Violence" in Sport and the Violenti non fit Iniuria Defence: A Perspective on the Death of the Cricket Player Phil Hughes" PER / PELJ 2018(21) - DOI http://dx.doi.org/10.17159/17273781/2018/v21i0a2409

\section{Copyright}

\section{DOI}

http://dx.doi.org/10.17159/1727-

3781/2018/v21i0a2409

\section{Abstract}

This article evaluates the defence of violenti non fit inuiria in sport with specific reference to the principle of bonos mores or the "good morals" in society to tolerate injuries in sport. The increased prevalence of serious injuries in sport in the professional era, in which sportsmen earn their livelihood from sport, necessitate a review of the existing situation. The death of the Australian cricket player, Phil Hughes, as a result of fast, short-pitched bowling in cricket, has again put the spotlight on the aggressive and excessive use of "violence" in sport. The malicious intent in sport, to harm or even to kill an opponent, has made it necessary to ask if there should be any difference in the manner in which the perpetrator of violence in sport should be treated as against ordinary criminal law assault and murder offenders. A two-pronged approach is suggested in the article as a possible way of dealing with wrongfulness in cricket.

\section{Keywords}

Defence of violenti non fit inuiria; contra bonos mores; wrongfulness; sport; cricket. 


\section{Introduction}

The occurrence of violence and injuries is not normally associated with sport and recreation. However, this "non-violent" perspective on sport does not align with the relatively large number of injuries that are intentionally inflicted on opponents during sporting contests. In an international context, the assumption that sport is basically a non-violent activity has already begun to change. In the United States of America the perspective on violence in sport was fundamentally altered in 1975 when there was a violent altercation in hockey, which resulted in a criminal prosecution for assault in State $v$ Forbes (hereafter the State $v$ Forbes case).$^{1}$ The perpetrator, David Forbes, struck his opponent, Henry Boucha, violently in the face and eyes with a hockey stick, causing serious injuries. Although this was the first notable prosecution in the USA related to violence in sport, in the same period in neighbouring Canada three players were charged for assault. ${ }^{2}$

The alarming fact is that even in non-contact sporting codes, such as cricket, serious injuries and even fatalities are not uncommon. In 2014 the Australian cricket player, Phil Hughes, was struck on the back of his head by a short-pitched delivery during an interstate match in Australia. During the match, the bowler, Sean Abbott, launched a series of short-pitched deliveries at Hughes before delivering the fatal blow which cost him his life. ${ }^{3}$ Abbott's teammate, Doug Bollinger, also a fast bowler, allegedly shouted to Hughes more than once during the bowling spell that he intended to kill him. A decision was made not to prosecute the bowler and the matter was dealt with in a post-mortem judicial probe chaired by the state coroner.

The high level of violence in sport has led to a commentator's once describing sport as "war without the shooting."4 In some sporting codes such as boxing, kick-boxing, ice hockey and even rugby, the physical confrontation has escalated to the point where it could be defined as borderline violence and, in some instances, full violence. In its broadest sense, violence is the use of excessive force which causes or has the potential to cause harm or serious injury to a fellow human being. The accepted general perception of violent actions in modern society is that they

Pieter Labuschagne. BA (Hons) MA D Phil (UFS) LLB LLM LLD (Unisa). Emeritus Professor, Department of Political Sciences, College of Human Sciences, UNISA, South Africa. E-mail: labuspa@gmail.com.

State $v$ Forbes No 63280 (Minn Dist Ct 1975) (hereafter the State v Forbes case). Anon 1976 Mich L Rev 148.

Telegraph Sport 2016 http://www.telegraph.co.uk/cricket/2016/10/14/angeredfamily-of-phil-hughes-walk-out-on-final-day-of-inquest-i/; Anon 2016 http://www.abc.net.au/news/2016-11-04/conflicting-statements-heard-during-philliphughes-inquest/7995410.

$4 \quad$ Chic, Loy and Miracle 1997 CCR 10-21. 
are regarded as illegal or unsanctioned. However, sport occupies such an elevated place in society that the use of violence and the related injuries are tolerated as long as they are within the rules. ${ }^{5}$

In South Africa there have been relatively few incidents of violence or of assault in sport that have resulted in prosecution and litigation. This is surprising given the intensity of some of the sporting codes and the accompanying overt intention to injure opponents. In Roux $v$ Hattingh (hereafter the Roux case) $)^{6}$ the plaintiff's neck was broken during a rugby game and the finding of the court was that the accused had a clear motive to inflict bodily harm.

The general perception is that injuries inflicted on an opponent take place only in contact sports, but in reality injuries could also be inflicted on opponents in non-contact sporting codes such as squash and cricket unintentionally, intentionally or maliciously. In Boshoff $v$ Boshoff (hereafter the Boshoff case $)^{7}$ a player suffered an injury during a squash match when he was struck by his opponent's racket. In an article titled "Cricket is riskier than your realise" the authors warned against the perception that there are fewer injuries in non-contact sports such as cricket than in other codes. ${ }^{8}$

When a player is injured in a sports event the physical injuries resulting from the positive conduct by the opponents and the presumption of wrongfulness could be deflected by establishing one of the well-settled defences in criminal law. The grounds of justification include private defence, necessity, and the defence of violenti non fit iniuria. ${ }^{9}$ The defence of violenti non fit iniuria relates to sport and medical procedures and is based on the principle that the injured party has consented to the act (the injury) or the possibility of injury. The "willingness" to take the risk of injury is conditional, based on specific provisos which will be pointed out in the article.

The aim of the article is to investigate the phenomenon of violence in sport in relation to the nature and the limits of violenti non fit iniuria as a viable defence. ${ }^{10}$ The focus of the article is an investigation into selected incidents of violence in sport, with special reference to cricket. The investigation will also look into the ability of a sports code, such as cricket, to deal appropriately with incidents where opponents have intentionally caused bodily harm to their opponents. The death of Hughes has called into question many of the existing assumptions and perceptions in the cricket

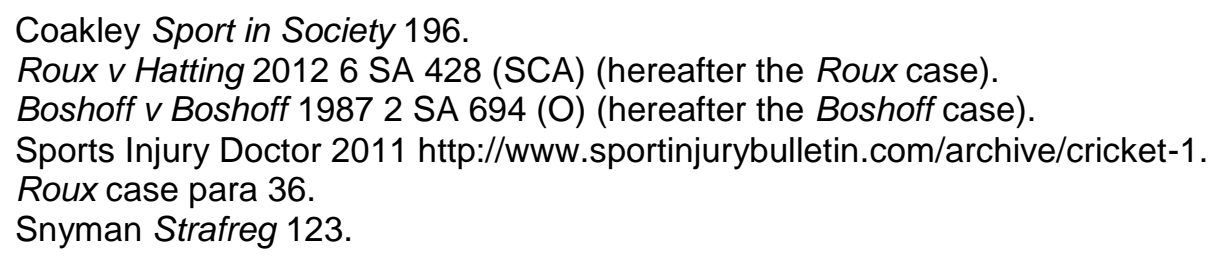


community that injuries are not as a result of malicious intent. This perception has prevailed for many decades, in spite of the high level of physical intimidation in cricket. In the last subsection of the article, the death of Hughes will be analysed with special reference to the fatal incident on the field. The subsequent discussion will then analyse the coroner's inquest.

\section{Violence in sport: a perspective}

The concept "violence" relates to the use of excessive force which causes or has the potential to cause serious harm or death to a fellow human being or human beings. In modern society, the unique perception exists that although violence is illegal or unsanctioned, its presence in sport is actually encouraged or approved, because of its excitement level. ${ }^{11}$ The presence of violence is not new to sport; in earlier societies, the so-called "blood sports" were popular among the ancient Greeks and throughout the Roman Empire. ${ }^{12}$ In the modern era, the most dangerous forms of these blood sports - such as duelling, prize fighting, boxing without gloves and even Russian roulette - have been declared illegal because of the high risk of injury, which has often resulted in death. In the modern era, sport is more rule-orientated and intolerant of extreme violence, which shift in ethos led to the decline of blood sports. In modern societies there is also a greater emphasis in sport on self-control to restrict physical contact and the expression of aggressive impulses towards an opponent. In the context of these developments in modern societies, spectators view "controlled" violence in sport as exciting and even "approve" of incidents that challenge the boundaries between "what is allowed and what is not allowed". ${ }^{13}$

The positive contributions of sport to society are numerous, which explains its acceptance and popularity. Chic, Loy and Miracle view sport as a spillover from the aggression exhibited in a pre-modern society to a domain in the modern society where it can be regulated and controlled. ${ }^{14}$ The downside is that the development of professional sport has again changed the inner values of sport as a stress releaser and a recreational activity. The sociologist, Eric Dunning, has noted that violence remains a crucial social issue in modern sport, because the participants' "goal is to create tension rather than relieve or discharge it."15

In modern society the emphasis that is placed on winning and "winning in sport at all costs" has changed the character of sport. A NFL coach once

Coakley Sport in Society 196.

Chic, Loy and Miracle 1997 CCR 10-21.

Houlihan Sport, Policy and Politics 62-146.

Chic, Loy and Miracle 1997 CCR 10-21.

Chic, Loy and Miracle 1997 CCR 10-21. 
said to his players, during a NFL draft, that his city is looking for "coldblooded defenders, who smile when the opposition quarterbacks bleed." Violence is also incorporated into game strategies, when coaches are picking designated agents of intimidation and violence for their teams. These players are often called "enforcers", "goons" and "hitmen", and they strategically assist their teams by intimidating members of the other teams. ${ }^{16}$

When a player partakes in sport, he or she does not consent to any actual bodily harm, but merely assumes the risk of such harm. As a result, not every act or omission in sport which inflicts injury, in general, is therefore actionable. As Harms JA in Telematrix (Pty) Ltd t/a Matrix Vehicle Tracking $\checkmark$ Advertising Standards Authority $S A^{17}$ stated, "everyone has to bear the loss he or she suffers". The Aquilian liability provides for an exception to the rule and, in order to be liable for the loss by someone else, the act or omission of the defendant must have been wrongful and negligent.

Thus, in sport, assault or injuries caused by dangerous or reckless play do not fall within the normal anticipated range of injuries a person can reasonably expect in a contact or non-contact sport. The injuries that occur as a result of malicious, dangerous and reckless play will therefore not be covered by a defence of consent (violenti non fit iniuria) and should be treated as criminal conduct and/or possible delict. ${ }^{18}$

\section{Liability for injuries in sport and the defence of violenti non fit iniuria}

In the Western Cape High Court, Brand JA made introductory remarks in the Roux case outlining the legal principles regarding injuries in sport and the applicable factors when a participant in sport (a rugby game) could be held liable for damages resulting from injuries inflicted on an opponent. Brand JA outlined the legal principle against the background of an earlier finding of the court a quo that there is clearly some confusion with regard to the approach that courts should adopt in the litigation of sports injuries.

In the United States of America, in the State $v$ Forbes case, the uncertainties regarding injuries in sport were also evident from litigation in which the perpetrator was prosecuted under the Minnesota criminal assault statutes. The culpability of Forbes, the perpetrator, was not decided, because the jury could not reach an agreement. The prosecutor subsequently declined to

\footnotetext{
16 Chic, Loy and Miracle 1997 CCR 10-21.

17 Telematrix (Pty) Ltd t/a Matrix Vehicle Tracking v Advertising Standards Authority SA 20061 SA 461 (SCA) (hereafter the Telematirx case) para 12. 
retry the case. However, the litigation signalled the start of an increase in the number of instances where the American courts had to deal with litigation resulting from sport injuries.

The uncertainties regarding culpability, as demonstrated in the State $v$ Forbes case, and the scope of the violenti non fit inuiria defence stress the need to look again at the scope of the defence. The necessity for additional analysis stems from the increase in the prevalence of violence in sport and the general assumption in society that sport is relatively violence free. The increasing number of injuries in sport has challenged the belief that injuries in sport are not the result of a malicious intent to injure. The notion of malicious intent in sport brings the contra bonos mores principle into the equation, because of its interrelation with the defence of violenti non fit inuiria. The standard or boundaries of the violenti non fit inuiria defence are set by the general perception of society (bonos mores). In this scenario, the principle of bonos mores relates to what the society deems to be moral and acceptable in sport.

Kotze $\mathrm{R}$ in the Boshoff case confirmed the conventional wisdom that a person "as the decider of its own faith" could consent to sustain reasonable injuries while partaking in sport. The injuries sustained in normal sport are not regarded as contra bonos mores when a bona fide participant unintentionally and reasonably injures a fellow player. The defence of violenti non fit inuiria, which includes knowledge, appreciation and consent, will therefore be viable as a defence in the event of possible prosecution. However, the court also stated that the notion of in volentem 'is not the notion to be injured, but only a juridical "will" to be injured' and to accept the risk of the injury.

In the United States of America, in People $v$ Samuels (hereafter the People $v$ Samuels case $)^{19}$ the court took the position "that it is common knowledge that a normal person in full possession of (his) mental faculties does not freely consent to the use upon himself of violence likely to produce great bodily harm". If the opponent has the malicious intent to injure his or her opponent, he or she could be liable for the injuries caused. Brand $J^{20}$ stated that in rugby, injuries are often caused with intent or, at least, caused in the sense of dolus eventualis, namely that the injuries were foreseen and the perpetrator persisted with the action. In these instances, liability will then follow if the negligent or intentional conflict is also held to be wrongful.

19 People v Samuels 250 Cal App 2d 501 (D Ct App 1967) (hereafter the People $v$ Samuels case).

20 Roux case para 32. 
The inflicting of injuries in sport in contravention of the rules controlling the game could still be regarded as not wrongful when an incident occurs normally in the course of the game. The tackling of a player after he has parted with the ball is a late tackle and is a contravention of the rules, but the umpire can deal with the incident by awarding a penalty. The incident and related transgression are punishable by awarding a penalty and, in more serious cases, a yellow or red card. In similar fashion, in cricket excessive and dangerous short-pitched balls delivered by a bowler could be punished by no ball calls and, in some cases, result in a decision by the umpires to suspend the bowler from further bowling during the match. However, malicious aggression with an excessive risk of injuries, such as delivering blows to and kicking an opponent in rugby or, in the case of cricket, bowling and targeting the head and face area of the batsman, are both unlawful and wrongful despite the initial consent of the injured. ${ }^{21}$

When a perpetrator's conduct differs from what he led the victim to expect, it could be argued that he exceeded the scope of what the victim had "agreed" to and was "willing to accept". If a player in rugby runs with the ball, he accepts that he will be tackled with the accompanied possibility of an injury. However, where the player is injured because of an unlawful tackle, there is therefore no "willingness" (agreement) to be injured. ${ }^{22}$ The boundaries or standards of what is acceptable and would qualify as consent are dictated by the good morals of society (bonos mores).

As Cornelius has indicated, the defence is not without its restrictions and will be available only if the defender can prove that the plaintiff's conduct meets the various requirements for the defence:

(a) The first requirement for the defence is that the consenting party must have had the capacity to act.

(b) The consent must have been given freely. That includes that the party must have been aware of the risk, must have understood the ambit of the risk and must have freely agreed to the risk.

(c) The permission must have been granted with the full awareness of the extent of any possible harm or risk.

(d) The consent must have been given with the full knowledge of what the consequences would be if the risk were actually to be realised.

(e) The party concerned must indeed have agreed to the risk of harm and injury.

$21 \quad$ Strauss 1964 SALJ 335.

22 Anon 1976 Mich L Rev 148. 
(f) The consent must have been acceptable according to the legal convictions of society. In other words, the incident must have happened according to the rules of the sport. ${ }^{23}$

As Strauss had indicated, the boundaries or the standard of consent are determined by adopting broad criteria such as "public policy", the "interest of the community", "injurious to the public", "the public welfare", "the good morals of society" and "the public interest". ${ }^{24}$ The broader approach to determining a standard of consent rests on the unlawfulness of the act and if the act was offensive to the "good morals" of society (contra bonos mores). This relates to the standard of morality and the extent to which it may be relaxed, and to the prevailing social view of what is lawful and what is unlawful.

Determining what may be contra bonos mores depends on the specific occurrence and the motives and objectives that existed in each case. When a rugby player is tackled late as part of the tactic to subdue and intimidate opponents the incident may be regarded as a borderline case, but the incident will not necessarily be repugnant to the "good morals of society". When a player tackles an opponent with a stiff arm with the objective and intentional motive of injuring the opponent, the act will be regarded as wrong and unlawful, because the act will be contrary to the "good morals of society". When a bowler bowls short-pitched deliveries to vary the length of his bowling attack and in the hope of finding the edge of the batsman's bat to create a catch for the fielders, these will be regarded as legitimate deliveries. This form or line of bowling will be considered as being within the scope of normal cricket, and will be accepted. However, when a bowler delivers short-pitched deliveries with the sole aim of injuring a player, accompanied with the high probability of injuries, the underlying motives would make the bowling contra bonos mores, and it should be considered as unlawful and wrongful.

Strauss emphasises that the nature and the seriousness of the injury and the nature of the objective of the act must and should play an important role in the determination of the moral aspects, in the interest of public welfare. The more valuable the object attacked - such as life, liberty and bodily integrity - the more likely it is that the aggression will be deemed to be in conflict with the good morals of society and, therefore, deemed as contra bonos mores. ${ }^{25}$

\footnotetext{
23 Cornelius 2016 GSLTR 7.

24 Strauss 1964 SALJ 335.

25 Strauss 1964 SALJ 183.
} 
Thus, when the injurious act is accompanied by a subjective malicious motive to cause harm, and/or by a particular awareness of the risk of serious harm that may follow, the act will be regarded as wrong. This proposition is opposed by those who subscribe to the thesis that wrongfulness is determined by the objective and the ex post facto criterion of reasonableness, and that the perpetrator's subjective mental disposition is therefore of lesser relevance. ${ }^{26}$ However, the view that is held in this article is that a subjective approach should be factored into the equation. When a player in rugby deliberately uses a stiff arm, or in cricket when a bowler delivers short-pitched deliveries to an opponent who is not in a position to defend himself against the aggression, the strategy should be viewed as wrongful. These assumptions are based on the motive and the intent of the perpetrator to harm, and his or her particular awareness of the risk and injury that may follow his or her actions.

The causality between the aim and the result is expressed and formulated in criminal law in dolus directus, dolus indirectus and or dolus eventualis, which in all cases attract liability for the wrongfulness or liability of the act. In the case of dolus directus, the effect or impact of the incident is the accused's actual aim and objective. In the case of dolus indirectus, the impact or effect of the incident is not the actual objective of the accused, but the perpetrators nevertheless foresee it as a certain or a virtually certain consequence of achieving the objective, and persist anyway. In the case of dolus eventualis, the result of the impact is not the actual aim or objective of the accused, but that he nevertheless foresees it as a possible consequence of achieving that objective and persists anyway. ${ }^{27}$

The combination of a negligent/intentional objective and the link with wrongfulness is therefore of critical importance regarding the decision on the wrongfulness of the act and possible culpability. If a bowler could anticipate that the batsman is vulnerable to fast bowling and that his line of attack on the opponent could cause serious bodily harm and he persists with the aggressive bowling (as will be indicated in the example below), then he should be culpable and charged under the criminal code for assault.

\section{Cricket: the intention to intimidate, the existence of actual consent and the injured party}

Strauss has indicated that the boundary or delimitation of consent is the standard of boni mores, which serves as the benchmark of the public interest. $^{28}$ If sport is played within the previously agreed rules, with the

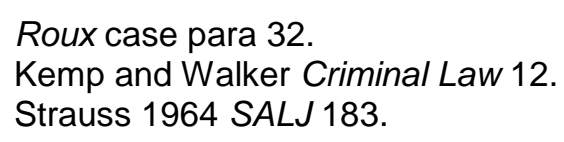


applicable consent (which includes the acceptance of the potential risk of injuries and related bodily harm), the act cannot be considered as contra bonos mores. ${ }^{29}$ However, when this set standard or delimitation of consent is exceeded, when excessive force was exerted during the game, and the motives and object of the impact on an opponent have exceeded the set standards, the act will be regarded as contra bonos mores. The more valuable the object targeted during the match, such as the life, liberty or bodily integrity of the opponent, the more likely it is that the perceived aggression of the perpetrator will be deemed to be in conflict with the good morals of society.

The perpetrator's intention, motive and objective are of the utmost importance, because it is evident of the motive (negligent or intentionally) and could therefore be regarded as either dolus directus, dolus indirectus or dolus eventualis. In the Roux case the court found that if an act was malicious and intentional, this would establish the fault element of Acquilian action. The malicious intent acted as a confirmation of the element of causation between the objective/motive and the outcome of the action.

The wrongfulness of the act could be determined by adopting a two-step process. The first step would be to establish if the action had taken place within the rules that govern the game. The second aspect that needed to be considered was if the tactic or the manoeuvre that caused the injury had been pre-planned with the specific aim of injuring the opponent. The causation of the two-step process is evident from the facts in the Roux case as outlined below.

In the Roux case Fourie $\mathrm{J}$ found that the perpetrator had deliberately, before the forwards had engaged in a scrum, moved to the injured player's right, with the intention of gaining a certain and pre-planned objective. The strategy was to scrum over his opponent (Hattingh) with the intention and inevitable consequence of injuring the opponent. The perpetrator called the specific code for this manoeuvre, namely "jack knife". He then moved into a pre-planned position to make it impossible for the injured player to enter into the correct channel. When the perpetrator had rendered his opponent vulnerable through the application of the strategy, he was able to apply the pressure that broke the victim's neck.

The wrongfulness of this act is located in the perpetrators action, which surpassed the standard set by the voluntary consent of the opponent and his/her "willingness" to suffer an injury. The conduct of the perpetrator was wrongful, deliberate and extremely dangerous, and a serious violation of the 
rules of the game. ${ }^{30}$ The deliberate act with the intent to injure (with the serious consequence of breaking an opponent's neck) was certainly contra bonos mores and exceeded the accepted standards of sport injuries that could be tolerated within modern society.

Cornelius notes the comment of Brand JA that a deliberate act that violates the rules may be excused in certain cases based on consent. He argues that this condones wilful misconduct and that it is contrary to the reputable principle that a party cannot evade liability for its own wilful misconduct. ${ }^{31}$

In United States of America, in the People $v$ Samuels case, ${ }^{32}$ the court took the position that it "is common knowledge that a normal person in full possession of [his] mental faculties does not freely consent to the use upon himself likely to produce great bodily harm".

However, there is an additional aspect that should be factored into the equation, besides the rules of the game, the standard of public awareness and bonos mores, namely the spirit of sport. Even in the modern era, a level of esprit de corps should prevail in professional sport between opposing teams or opponents to ensure that the game is played in a good spirit and that good sportsmanship is demonstrated. In rugby, if a hooker is forced to replace a prop as a result of an injury, his direct opponent should realise his vulnerability and refrain from over-aggressive scrumming. When a batsman shows vulnerability to high-pitched deliveries, which could potentially endanger his head area, the bowler should acknowledge it and not exploit the situation. The bowler should realise that his action falls outside the rules of the game, not only with regard to the "permission to be injured" principle, but also because the aggressive bowling, with the specific motive and objective to injure, would be contra bonos mores. The more valuable the object that the bowler attacks such as the life, liberty and bodily integrity of the batsman, the more likely it is that the perceived aggression of the perpetrator will be deemed in conflict with the good morals of society.

In cricket, aggressive fast bowlers have for years unquestionably been testing the thin line between dangerous bowling and bowling within the set standards. The accepted standard for bowlers is delimited by two principles, namely the violenti non fit iniuria defence and the standards and boundaries set by the bonos mores principle.

The accepted standard of bowling has been exceeded for many years, and it could have led to possible prosecution in the past. For instance, in South

Roux case para 41.

Cornelius 2016 GSLTR 7.

People v Samuels case 513-514. 
Africa's first match in the 1995 World Cup Cricket tournament in England, they had to play against the United Arab Emirates team. The United Arab Emirates was not regarded as a test playing nation and its players were mostly inexperienced and untested within the international cricketing arena. When their captain, Sultan Hirwani, walked to his batting crease to open the batting, he was wearing only a soft hat and not the normal protective helmet. The express South African fast bowler, Allan Donald, was opening the bowling for South Africa. Donald was initially hesitant to bowl aggressively to the "unprotected" batsmen. However, he was encouraged by one of the senior players to strike Hirwani on the head to teach him the lesson that he needed to wear a helmet. Donald responded and deliberately aimed his first delivery to Hirwani's head. The delivery caught Hirwani on the left temple and floored him for some time, but fortunately he was not seriously injured. ${ }^{33}$ Donald had made his intention (dolus eventualis/dolus directus) and objective clear through his line of bowling. If the player failed to "protect" himself, he would have to deal with the consequences.

In the light of the principles governing injuries in sport, the batsman (Hirwani) had voluntarily consented to be exposed to injuries, but within the rules. The "offender" in the example (Donald), on the other hand, knew his opponent's vulnerability and acted upon this, with the full knowledge of the potential high risk of an injury. The incident serves as a classic example of dolus eventualis or dolus directus; Donald foresaw the possibility of the injury and it was his aim, intention and objective to injure his opponent. (In this example it was fortunate that the batsman was not seriously injured.)

With the acceptance in cricket of the aggressive nature of short-pitched bowling for decades, it was just a matter of time before a tragedy would occur. It thus came as no surprise in 2014 when, during a match between South Australia and New South Wales, the persistent, aggressive, shortpitched bowling by Abbot resulted in the death of Phil Hughes of South Australia. This incident again highlighted the potential dangers of an overaggressive strategy in sport, even in a non-contact sport such as cricket. ${ }^{34}$ During the game, Hughes was struck by a short ball on the back of his head,

33 Donald White Lightning 160.

34 David, Wolman and Fyfe 1989 BMJ 1574. The authors outline in their article the increase in the number of serious injuries in non-contact sports such as cricket. They point out that head injuries in cricket are the most common injuries sustained, and that the number of incidents is on the rise (Sports Injury Doctor 2011 http://www.sportinjurybulletin.com/archive/cricket-1). The British Council Sport Survey has found that there are 2.6 serious injuries in cricket in England for every 10000 hours of play. In Australia the number is as high as 24 serious injuries for every 10000 hours of play. 
and he collapsed. He passed away two days later. ${ }^{35}$ The bowler, Sean Abbott, delivered the fatal ball that killed Hughes while his bowling spell teammates shouted that they intended to kill the batsman. This threat was part of the on-going sledging on the field during the match. ${ }^{36}$ However, this allegation was subsequently denied by Abbott and his teammates at the judicial hearing, overseen by the state coroner. However, the media unearthed evidence that showed that the use of short-pitched deliveries was discussed in the dressing room as the strategy for the match - this form of attack was maintained throughout the match - and that Bollinger actually had made the threat during the match. ${ }^{37}$

The father and the family of the victim (Phil Hughes) walked out of the coroner's inquest disgusted by the denials, the lack of accountability of the perpetrators, and the emphasis that was placed at the hearing on the need to "learn lessons from the incident" rather than to deal with the perpetrator. Phil Hughes' father declared Sydney Cricket Ground to be an unsafe workplace and identified the large number of short-pitched deliveries that were bowled to his son, while he received no assistance or protection from the umpires, as the reason for his death. ${ }^{38}$ The state coroner conceded that there would naturally have been sledging during the game. However, he made the debatable statement that the dangerous deliveries did not in themselves negate Hughes' capacity (and responsibility) to defend himself. 39

In his findings the coroner, Michael Barnes, stated that there had been no malicious intent on the part of the bowler and that Hughes could have avoided the ball by ducking under it. That last remark at the inquest shifted the responsibility to the victim and will be scrutinised more thoroughly in the next subsection.

\section{The Hughes incident: the defence of violenti non fit iniuria, as against contra bonos mores and wrongfulness}

As Cornelius indicates, organised sport takes place in accordance with complex contractual relationships. Conscious disrespect of a rule of sport is

35

The British Council Sport Survey has found that head injuries are the most common injuries in cricket and account for more than $25 \%$ of all injuries (Sports Injury Doctor $2011 \mathrm{http}: / /$ www.sportinjurybulletin.com/archive/cricket-1).

36

37

38

39

Anon Beeld 15.

Anon Beeld 15.

Telegraph Sport 2016 http://www.telegraph.co.uk/cricket/2016/10/14/angeredfamily-of-phil-hughes-walk-out-on-final-day-of-inquest-i/.

Anon 2016 http://www.abc.net.au/news/2016-11-04/conflicting-statements-heardduring-phillip-hughes-inquest/7995410. 
therefore not only wilful misconduct but also amounts to the deliberate breech of a contractual obligation to play in a certain way within the rules. ${ }^{40}$

In order to contextualise the possible culpability that resulted from the death of Hughes, ${ }^{41}$ it is important to investigate the laws regulating cricket, more specifically the laws on fast, short-pitched bowling. The bowling of fast, short-pitched balls is technically dealt with under the category of "dangerous and unfair bowling" in the laws of the International Cricket Council (ICC) under rules (6)-(8). Rule 6(a) outlines the technical aspects of dangerous and unfair bowling as follows:

The bowling of fast balls is dangerous if the bowlers and umpire consider by their repetition and taking into account their length, height and direction that they are likely to inflict physical injury on the striker irrespective of the protective clothing he may be wearing. ${ }^{42}$

It is important to note the crucial role that is assigned to the umpire at the bowlers end as the sole judge of dangerous deliveries. The rules have already restricted the number of fast short-pitched balls to one ball per over, based on the length, height and direction of the deliveries. However, the dangerous aspect of bowling is not addressed other than ex post facto, when the injury has already occurred in the case of a second delivery in the same over. In rule 6(a) the responsibility "to protect" is not placed on the batsman (who could otherwise have been required to protect himself or to avoid the delivery) but on the umpire, who is required to protect the batsman from dangerous bowling by calling a no ball or, in persistent cases, suspending the bowler. In addition, Rule 6 also deals with other dangerous deliveries, such as one that would be above the waist height.

In the case of rule (7), if a delivery is ruled a dangerous or deemed an unfair delivery (as in rule 6(a)) the umpire should call and signal a no ball. When the line of bowling persists and the bowler does not adhere to the restrictions placed on him, rule (8) will apply. Rule (8) authorises the temporary suspension of the bowler. The rule equips the umpires with extensive powers to act in situations where the safety of players is compromised. Indeed, the umpires regularly act in the interest and safety of a bowler and

$40 \quad$ Cornelius 2016 GSLTR 8.

41 Sports Injury Doctor 2011 http://www.sportinjurybulletin.com/archive/cricket-1. 7 players have lost their lives during cricket matches since 1989. In 1993 lan Folley of England died as result of an eye injury, Darryn Randall of South Africa died in 2013 as result of an injury sustained during a match, while the most recent death is that of Phil Hughes, who died as result of the fast high pitched delivery that struck him against his head. The frequency of injuries in cricket is actually on the rise with $71 \%$ of cricket players having suffered mild to serious injuries playing cricket during their careers. 
do not hesitate to call off matches if the playing surface is not up to standard, because the batting strip and the field are unsafe for the players. ${ }^{43}$

Three aspects from the judicial inquest into the death of Phil Hughes are singled out for further discussion. The incidents relate to applicable criminal law and rules (6)-(9) of the International Cricket Board.

The findings of the coroner, Michael Barnes, on the conclusion of the inquest, were that:

(i) better protective clothing could have prevented the fatal injury. (The improvement of the helmets since the incident has certainly addressed the inadequacy of the older helmets by extending it to protect the back of the head).

(ii) there was no malicious intent from the bowler to cause the death of the batsman.

(iii) the batsman (Hughes) could have avoided the fatal injury to his own head by ducking under the ball.

The curious aspect of the hearing and the findings was that the inquest shifted the focus and responsibility from the perpetrator (the bowler) to the victim (the batsman) and to the inadequacy of the protective clothing (the helmet). It is informative to revisit law 6(a), specifically the last section of the law "... that they [the fast, short-pitched balls] are likely to inflict physical injury on the striker irrespective of the protective clothing he may be wearing" (own emphasis). It is clear that the inadequacy of the clothing is not a mitigating factor and the fact that the helmet did not protect the back of the head should not be factored into the argument.

With reference to findings (ii) and (iii) above, during the judicial post-mortem the state coroner decided to hear testimony from advocates who preferred to focus on the lessons that could be learned from the incident rather than to assign blame. ${ }^{44}$

The point was that a human being was killed and there was certainly evidence of malice on the part of the perpetrator, which exceeded the set principles in law and those enacted in sport to combat such events. Rule (6)-(9) clearly and unambiguously assigns a responsibility to the umpire to act and to declare a delivery dangerous and/or unsafe. The first step is to penalise the deliveries as no balls. If the dangerous and unsafe bowling persists, the umpire is obliged (according to rules (6)-(9)) to take more

Anon Beeld 15.

Anon Beeld 15; Anon 2016 http://www.abc.net.au/news/2016-11-04/conflictingstatements-heard-during-phillip-hughes-inquest/7995410. 
drastic measures, which may include the temporary suspension of the bowler.

In spite of the evidence before him the coroner accepted that there was no malicious attempt to hurt Hughes. However, Hughes' teammates had testified that there had been a barrage of short-pitched bowling accompanied by threats by the bowler, who suggested that he intended to kill the batsman. The fact was that Hughes subsequently died as a result of such a delivery, which established causality between the threat and the outcome. ${ }^{45}$ It is superfluous to argue that Hughes should have taken evasive action and therefore to argue that he caused his own fate. The principal and fundamental duty of the umpire was to protect the batsman, if the latter is unable to avoid or deflect the deliveries. The onus should not have been shifted to the batsman or even to the protective clothing to prevent the infliction of physical injury on the striker (rule (6)(a), irrespective of the protective clothing he may have been wearing.

The coroner preferred to isolate and emphasise two aspects: the responsibility of the batsman to duck under the delivery, and suggestions on how to improve the quality of the safety equipment. In the first instance, if we accept the finding that it is the responsibility of the batsman to duck under the ball to avoid injury, this would create an untenable position. In criminal law, if a person aims to shoot at a victim with the intention to wound or to kill him, the responsibility cannot be shifted to the victim by arguing that he could have ducked to avoid being shot.

The bowler (Abbott) allegedly shouted during the incident that he was going to kill the batsman, which clearly establishes a motive or intention of dolus to kill. The incident and the subsequent events are certainly not tolerable within the standards set by society and are contra bonos mores of the level of injury that society will tolerate in sport. If it is accepted that Abbott's threats were acceptable because they were made within the context of a game, would this imply that different standards are set for criminal law as opposed to incidents of violence in sport?

\section{Conclusion}

If different standards were to be implied in criminal law for murder and assault as opposed to what is applicable in sport, this would provide for an interesting scenario. If a perpetrator declares his intention to kill a fellow human being and follows through by actually killing the victim, the causality

45 Telegraph Sport 2016 http://www.telegraph.co.uk/cricket/2016/10/14/angeredfamily-of-phil-hughes-walk-out-on-final-day-of-inquest-i/. 
is clearly formed. If the same scenario unfolds in a match where a threat is made and then followed through, why should a different set of rules apply?

The increasing violence in sport in the United States of America has called into question many of the assumptions that society has made about athletic contests, notably the belief that injuries in sport are not the product of a malicious intent to injure. The increased violence in professional hockey, where physical intimidation is commonplace, has certainly challenged this view. ${ }^{46}$ The increase in violence in sport in the United States of America and in Canada has certainly resulted in an increase in the number of prosecutions of the offenders. ${ }^{47}$

In the Roux case there was certainly an intention to injure the opposing player, although it is doubtful if the intention was to break the opponent's neck. In Abbott's case there was also the intention to cause harm to Hughes with the short-pitched balls, although it could be argued that the bowler (in spite of his verbal threats) did not intend to kill him. This proposition rests on the age-old perspective that assault in sport may differ from other kinds of assault, because the participants are thought not to possess the requisite mens rea. The popular view is that people participate in athletics and in sport out of the love of the game and not because of a malicious desire to harm opponents.

There is larger social tolerance of serious injuries suffered in sport, because people generally view the beneficial aspect of sport favourably and are therefore more tolerant of aggression in sport. However, this position may change in future if sport administrators do not respond timeously and act against open aggression and malicious acts in sport. The glossing over of the Hughes tragedy has done little to improve the image of the sport, although it brought about technical changes to the equipment of cricket players. However, this matter is peripheral to the more deeply-seated problem of over-aggressive behaviour on the cricket field.

As Cornelius ${ }^{48}$ clearly indicates, sport will not be able to hide any longer behind consent and the acknowledgement of the risk of injuries. In international and national sport there is clearly a reluctance to accept the defence. Cornelius refers to Agar v Hyde, ${ }^{49}$ where the Chief Justice stated that:

Voluntary participation in a sporting activity does not imply an assumption of any risk which may be associated with the activity, as to negate the existence

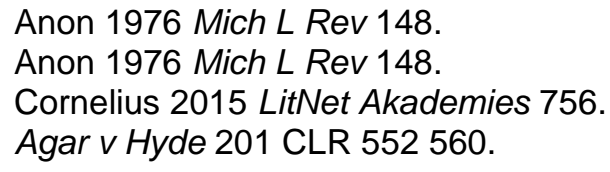


of a duty to care in any other participant or in any other person in any way involved or connected with the activity.

It has been emphasised in this article that society's standards and the scope of consent to tolerate sport injuries are dictated by the prevailing norms and "good morals" of society. However, the increasing number of injuries in modern sport may progressively challenge this tolerance of harm. A change in the societal perspective may produce a different and higher standard with regard to accountability when adjudicating injuries in sport that were caused intentionally with the aim of injuring an opponent.

It is foreseeable, in the light of the increased professionalism in sport, and with an increasing number of people earning their livelihood from sport, that the social tolerance of the intentional and malicious causing of injuries to opponents may be tempered in the near future. The response to this situation would require making a two-pronged approach. Firstly, a judicial position should be taken that would show less tolerance to intentional injuries in sport. It is evident that the gap between common assault and the causing of intentional injuries in sport should be closed, because they are regulated by the same principles. The second approach would require the governing bodies to apply the rules and laws of the sport much more strictly and for this to serve as a deterrent. There are definite signs in cricket that there will be a clampdown in future on dangerous bowling. The new laws, which will be in force soon, make provision for the curbing of persistent dangerous bowling and allow the umpires to suspend the bowler for a period of time during which he has to leave the field of play. These steps, if taken, would ensure the safety of cricket players and would be welcomed in the cricket fraternity.

\section{Bibliography}

\section{Literature}

Anon 1976 Mich L Rev

Anon "Consent in Criminal Law: Violence in Sports" 1976 Mich L Rev 148179

Anon Beeld

Anon "Bollinger wou Hughes Glo Doodboul" Beeld (15 March 2016) 15

Chic, Loy and Miracle 1997 CCR

Chic G, Loy JW and Miracle AW "Combative Sport and Warfare: A Reappraisal of the Spill-over and Catharsis Effect" 1997 CCR 10-21 
Coakley Sport in Society

Coakley J Sport in Society: Issues and Controversies. (McGraw Hill New York 2007)

Cornelius 2015 LitNet Akademies

Cornelius S "Wat die Drome nie Genees nie: Kan Toestemming tot Benadeling steeds Aanspreeklikheid weens Sportbesering Uitsluit?" 2015 LitNet Akademies 756-788

Cornelius 2016 GSLTR

Cornelius $S$ "The Expendibles: Do Sport People Really Assume the Risk of Sport?" 2016 (7)1 GSLTR 6-11

David, Wolman and Fyfe 1989 BMJ

David HG, Wolman R and Fyfe I "Cricketing Casualties and Sporting Siblings" 23-30 December 1989 BMJ 1574-1674

Donald White Lightening

Donald A White Lightening: Allan Donald - The Autobiography t(Human and Rousseau Cape Town 1999)

Houlihan Sport, Policy and Politics

Houlihan HR Sport, Policy and Politics: A Comparative Analysis (Routledge London 1997)

Kemp and Walker Criminal Law

Kemp G and Walker S (eds) Criminal Law in South Africa (Oxford University Press Cape Town 2012)

Snyman Strafreg

Snyman CR Strafreg $4^{\text {th }}$ ed (Butterworths Durban 1999)

Strauss 1964 SALJ

Strauss SA "Bodily Injury and the Defence of Consent" 1964 SALJ 332-345

\section{Case law}

Agar v Hyde 201 CLR 552

Boshoff v Boshoff 19872 SA 694 (O)

People v Samuels 250 Cal App 2d 501 (D Ct App 1967)

Roux $v$ Hatting 20126 SA 428 (SCA) 
State v Forbes No 63280 (Minn Dist Ct 1975)

Telematrix (Pty) Ltd t/a Matrix Vehicle Tracking $v$ Advertising Standards Authority SA 20061 SA 461 (SCA)

\section{Internet sources}

Anon 2016 http://www.abc.net.au/news/2016-11-04/conflicting-statementsheard-during-phillip-hughes-inquest/7995410

Anon 2016 Phillip Hughes: Sledging, Bowling were Focus of Much of Inquest into Cricketer's Death http://www.abc.net.au/news/2016-1104/conflicting-statements-heard-during-phillip-hughes-inquest/7995410 accessed 15 April 2017

MCC 2017 https://www.lords.org/mcc/laws-of-cricket

Marylebone Cricket Club 2017 Laws of Cricket https://www.lords.org/ mcc/laws-of-cricket accessed 3 April 2017

Sports Injury Doctor 2011 http://www.sportinjurybulletin.com/archive/ cricket-1

The Sports Injury Doctor 2011 Epidemiology of Injuries http://www.sportinjurybulletin.com/archive/cricket-1 accessed 15 April 2017

Telegraph Sport 2016 http://www.telegraph.co.uk/cricket/2016/10/14/an gered-family-of-phil-hughes-walk-out-on-final-day-of-inquest-i/

Telegraph Sport 2016 Angered Family of Phil Hughes Walk Out on Final Day of Inquest into Cricketer's Death http://www.telegraph.co.uk/cricket/ 2016/10/14/angered-family-of-phil-hughes-walk-out-on-final-day-ofinquest-i/ accessed 15 April 2017

\section{List of Abbreviations}

$\begin{array}{ll}\text { BMJ } & \text { British Medical Journal } \\ \text { CCR } & \text { Cross-cultural Research } \\ \text { GSLTR } & \text { Global Sports Law and Taxation Report } \\ \text { ICC } & \text { International Cricket Council } \\ \text { MCC } & \text { Marylebone Cricket Club } \\ \text { Mich L Rev } & \text { Michigan Law Review } \\ \text { NFL } & \text { National Football League } \\ \text { SALJ } & \text { South African Law Journal }\end{array}$

